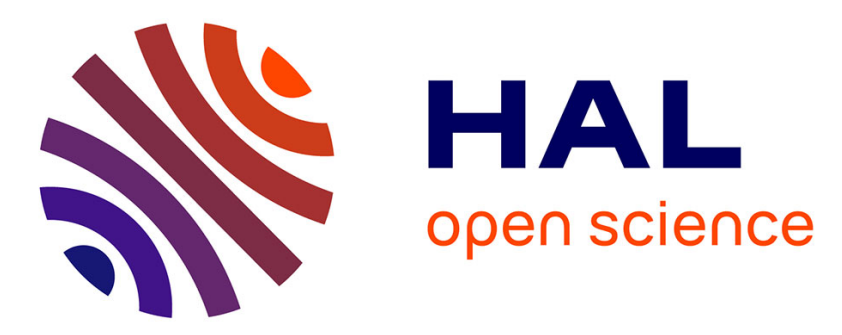

\title{
Infrared differential imaging of vertical and slanted cracks : modelisations and experiments
}

\author{
J. Guitonny, Z. Bozoki, A. Mansanares, M. Le Liboux, D. Fournier, A. \\ Boccara
}

\section{- To cite this version:}

J. Guitonny, Z. Bozoki, A. Mansanares, M. Le Liboux, D. Fournier, et al.. Infrared differential imaging of vertical and slanted cracks: modelisations and experiments. Journal de Physique IV Proceedings, 1994, 04 (C7), pp.C7-607-C7-610. 10.1051/jp4:19947143 . jpa-00253201

\section{HAL Id: jpa-00253201 https://hal.science/jpa-00253201}

Submitted on 1 Jan 1994

HAL is a multi-disciplinary open access archive for the deposit and dissemination of scientific research documents, whether they are published or not. The documents may come from teaching and research institutions in France or abroad, or from public or private research centers.
L'archive ouverte pluridisciplinaire HAL, est destinée au dépôt et à la diffusion de documents scientifiques de niveau recherche, publiés ou non, émanant des établissements d'enseignement et de recherche français ou étrangers, des laboratoires publics ou privés. 


\title{
Infrared differential imaging of vertical and slanted cracks: modelisations and experiments
}

\author{
J. Guitonny*, Z. Bozoki(1), A.M. Mansanares, M. Le Liboux, D. Fournier* and A.C. Boccara \\ Laboratoire d'Optique, ESPCI, UPR A0005 du CNRS, 10 rue Vauquelin, 75005 Paris, France \\ * Laboratoire d'Instrumentation, ESPCI, 10 rue Vauquelin, 75005 Paris, France
}

\begin{abstract}
A differential stimulated I.R. detection scheme is presented in order to obtain a better contrast in crack detection on real samples whose surface exhibits topographical and optical irregularities. A finite element simulation confirms the magnitude and shape of the signals for vertical and slanted cracks.
\end{abstract}

\section{INTRODUCTION}

Photothermal techniques showed themselves particularly adapted for the detection of surface or subsurface cracks [1]. We present here a differential infrared radiometry experiment wich allows us to show a large signal contrast enhancement in comparison with a single detection scheme. Moreover this method allows us to reduce the effects of surface optical and geometrical properties variations. Some years ago, different experiments have been carried oud using alternating beam method [2], or local beam modulation [3]. In this both case, the laser beam is spatially modulated, in our case the laser beam is temporaly modulated.

\section{PRINCIPLE}

The sample surface is heated with a focused and modulated gaussian laser beam. This heating source induces thermal waves inside the material which propagate in the solid. The temperature of any point on the surface is characterized by an amplitude and a phase which depend on the position of the point with respect to the heating source. When there is no barrier to the propagation of heat and when the medium is isotropic the temperature map on the surface is perfectly symmetrical. If a thermal barrier, like a crack, prevents the propagation of thermal waves, the temperature map is changed and the symmetry is broken. In a monodetection scheme, the sensitive element measures a global variation of the surface temperature and the contrast is poor. With differential detection, the image of the exciting spot is centered between the two detector sensitive elements and the recording is the difference between the signals given by the two cells. By this way the background is rejected, the contrast is enhanced and one can take into account the dissymmetry of the temperature map.

The modification of thermal waves propagation will be different according to the kind of defect; nevertheless a thermal barrier like a crack, induces reflected waves which increase the surface temperature. Only the analytical model of Mc Donnald [4] gives an exact solution for the surface temperature for a vertical crack. So, we built a model for the slanted cracks cases, based on a finite element program (Algor), and we checked the validity of this numerical approach by comparing the results obtained for a

(1) Permanent address: Institute of Isotopes, Budapest, Hungary 
vertical crack with the analytical model. The results are in good agreement both in amplitude and phase, which make us confident in the slanted crack calculation.

Different samples with vertical or slanted cracks have been studied. We will limit ourselves here to results obtained with a steel sample exhibiting a $20^{\circ}$ slanted crack which is made of two pieces kept in contact. It is important to emphasize that the sample surface is not perfectly polished, so optical absorption and surface emissivity variations are large. Therefore, this sample is absolutely not a laboratory sample and measurements carried can mimic realistically non destructive evaluation situations

\section{EXPERIMENTAL SET UP}

In a preliminary experiment [5], the sample irradiation point and the detector were conjugated using a spherical mirror, and the residual aberrations were large enough to prevent us from getting a larger contrast improvement. The results that we fast obtained were performed along single scan lines, whereas the results presented here demonstrate the validity of our approach over full images analysis.

With the experimental set up used (fig. 1), we can obtain 3D maps. The argon laser beam is focused on the sample with the help of a lens which allows to modify the optical spot diameter on the surface and therefore the diameter of the exciting source. By varying this diameter and the exciting frequency, one can change the size of the heated region and the depth of thermal waves. The infrared and visible fluxes are collected by a Cassegrain objective which has a large working distance and an etendue of the beam big enough to have a sufficient flux. A dichroïc mirror allows to separate the infrared and visible light. The visible light is focused on a power meter in order to measure the reflected visible flux. The infra red beam is focused on the detector wich is cooled at liquid nitrogen temperature. The detector is made of two HgCdTe cells. The size of cell is $250 * 250 \mu \mathrm{m}$ and the gap is $30 \mu \mathrm{m}$. Whith the optical device used, it is possible to change the magnification. That is to say, the surface "seen" by one cell is $70^{*} 70 \mu \mathrm{m}$ for the 3.7 magnification and about $500 * 500 \mu \mathrm{m}$ for the 0.5 magnification.

So, we are able to carry out experiments in monodetection or bidetection. In the first case, the optical spot is centered on one cell. When the sample is translated, we measure the amplitude and the phase of the signal at each point. In our experiment we scanned a surface of $1 \mathrm{~mm}$ by $1 \mathrm{~mm}$. In the second case, the optical spot is centered on the gap, and the detector is adjusted in order to balance the two cells. It is important to emphazise that we balance the detector far from the crack, but because of the optical heterogeneity of the surface, it is impossible to obtain no background on the whole surface. Data acquisition as well as sample displacement (Micro Controle translation stage) are controlled by a PC (486 microcomputer).

\section{RESULTS}

Different cases in monodetection and differential detection have been studied with different optical spot sizes and two different optical magnifications. The experimental results shown were carried out under the same conditions (spot size : $170 \mu \mathrm{m}$ and magnification 0.5 ) in order to give a better comparison. On figure $2 a$, with a single detection, one can see that it is impossible to detect the position of the crack on the amplitude signal wich is strongly depending on optical, geometrical and thermal properties of the surface. Indeed, the amplitude variation due to differences of local surface properties can exhibit the same magnitude as the signal induced by the crack. In some cases, when the magnification is larger and the spot size smaller, the signal due to the crack appears, but the local effects are more important. The phase (figure $2 \mathrm{~b}$ ) is generaly less sensitive to local effects, and we can see the crack parallel to the $\mathrm{x}$ axis, but phase variations are weak ( 2 or 3 degree as expected with the models). In differential detection, in all cases, the crack appears clearly. On figure $2 \mathrm{c}$, the amplitude signal due to the crack is very important and the local effects are relatively slight. Under those conditions, the background is not completely eliminated but the contrast is very important. For the phase (figure $2 \mathrm{~d}$ ), we can see also the crack. The phase variations are very large, about 90 degrees. According to the cases, it is possible to reduce the spatial size of phase signal, that is to say, to enhance the resolution. Indeed, when increasing the magnification and decreasing 
the optical spot, the heated region is smaller and the signal is stretching on a shorter length. But in this case the amplitude is more sensitive to the local optical effects.

\section{CONCLUSION}

With the experiments carried out, we have clearly shown that we can strongly enhance the signal contrast due to the crack using a differential detection method. Moreover, this method being less sensitive to surface effects than a single detection, it is easier to detect a defect signature.

\section{References}

[1] Grice K. R. Inglehart L. J., Favro L. D., Kuo P. K, and Thomas R. L., J. Appl Phys. 54 (November 1983) 6245-6255.

[2] Lehto A., Jokinen M., Jaarinen J., Tiusanen T., Luukkala M., Electr. Lett. 17 (1981) 540-541.

[3] Busse G., Optics Communications 36 (1981) 441-443

[4] McDonald F. A., Wetsel G. C., Jamieson Jr, and G. E., Can. J. Phys. 64 (1986) 1265-1268.

[5] Guitonny J., Bozoki Z., Mansanares A. M., Le Liboux M., Foumier D., Boccara A. C., Optics Communications 104 (december 1993) 61.

\section{Experimental set-up}

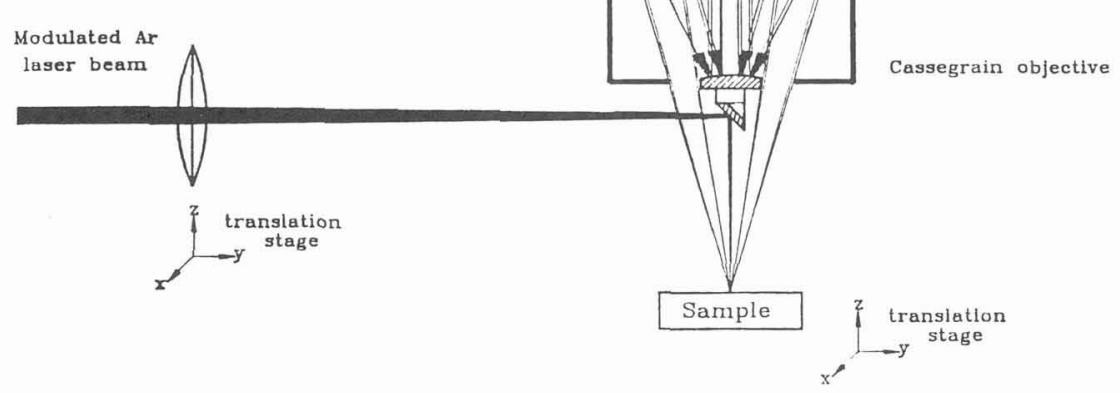



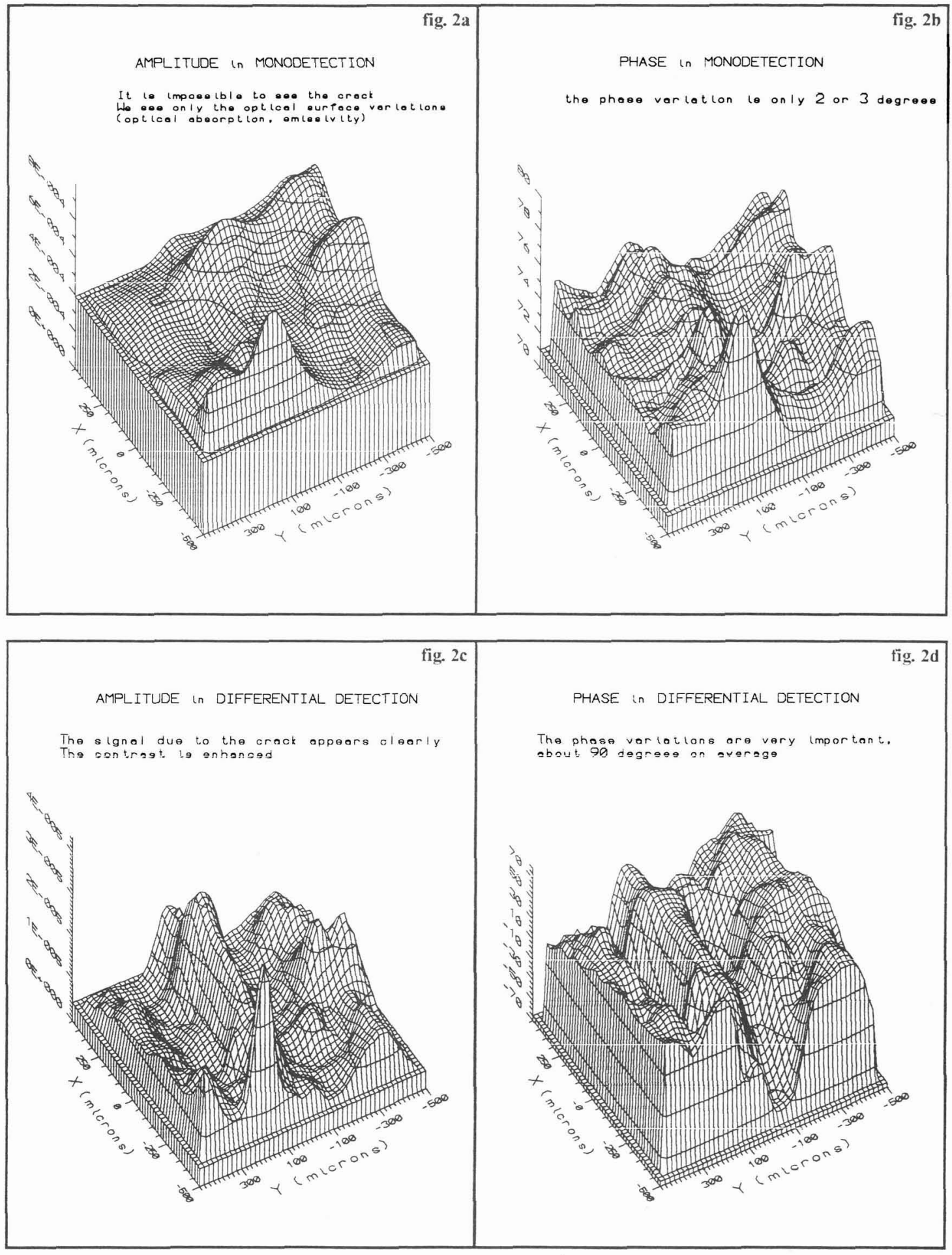

figure 2 : Curves obtained in monodetection and differential detection 